\title{
ОРГАНІЗАЦІЯ АУДИТУ В СЕРЕДОВИЩІ УПРАВЛІНСЬКИХ ІНФОРМАЦІЙНИХ СИСТЕМ
}

\section{Рецензент - доктор економічних наук В. Я. Плаксіснко}

Узагальнено й систематизовано підходи вітчизняних $і$ зарубіжних вчених щзодо організації аудиту. Запропоновано визначення організації аудиту на основі аналізу основних складових організаџійної діяльності, щзо здійснюється на основі управлінських інформаційних систем і технологій. Враховуючи специифічні ознаки аудиту, його види та цілі здійснення, авторами запропоновано складові організації аудиторського прочесу. До того ж внутрішні й зовнішні процеси, пов'язані з організацією аудиту, можуть бути реалізовані різними електронними методами.

Ключові слова: організачія аудиту, управлінські інформаційні системи, комп'ютерне середовище, комп'ютерні інформаційні системи підприємств (КІСП) та комп'ютерні системи бухгалтерського обліку (КСБО).

Постановка проблеми. Швидкий розвиток управлінських інформаційних систем і технологій та впровадження їх у всі сфери нашого повсякденного життя зумовлює необхідність інтеграції процесів аудиту в управлінські інформаційні системи. Використання інформаційних технологій у проведенні аудиту викликає необхідність як із боку аудиторів впроваджувати сучасні комп'ютерні інформаційні системи на аудиторських фірмах i компаніях, так i 3 боку суб'єктів господарської діяльності. Даний процес допоможе підвищити якість і ефективність проведення аудиту за умови вирішення певних завдань.

Аналіз останніх досліджень і публікацій, у яких започатковано розв'язання проблеми. Теоретико-методологічними дослідженнями проблемних питань організації аудиту свої праці присвятило чимало вчених, зокрема Д. В. Єременко [3], О. А. Петрик [4], О. Ю. Редько [5]. Водночас, розглядаючи теоретико-методологічні засади формування й розвитку організації аудиту, актуалізується питання необхідності подальшої розробки даного напряму 3 урахуванням розвитку управлінських інформаційних систем.

Проблемні питання управлінських інформаційних систем знайшли відображення у працях таких вітчизняних вчених: Ф.Ф. Бутинця,
С. В. Івахненкова [1], В. П. Завгороднього, І. С. Литвина, Г. В. Федорова [7], В. Д. Шквір.

Питанням автоматизації аудиторської діяльності в своїх дослідженнях приділяли значну увагу такі науковці як С. В. Івахненков [2], Б. В. Кудрицький, О. О. Назаренко, Л. О. Терещенко [6], Б. Ф. Усач та інші.

Мета і завдання дослідження. Метою даної статті є визначення наукового поняття організації аудиту в середовищі управлінських інформаційних систем.

Завданням є висвітлення результатів досліджень із проблеми організації аудиту в середовищі управлінських інформаційних систем, включаючи і власні дослідження.

Матеріалами досліджень стали наукові праці вітчизняних i зарубіжних науковців, а також нормативні документи.

Методами досліджень є узагальнення та систематизація, аналіз і синтез.

Результати дослідження. В умовах сьогодення інформаційні системи охопили всі сфери нашого повсякденного й ділового життя. Використання інформаційних технологій дають можливість підвищити ефективність функціонування підприємств та організацій через зменшення термінів внесення й обробки даних, а також спрощення обліково-аналітичної роботи працівників.

Інформаційні системи вже тривалий час розвиваються і функціонують у галузі бухгалтерського обліку. Однак складання та подання фінансової звітності в електронному вигляді з використанням баз даних бухгалтерських програм розвивається недостатньо швидко, як й інформатизація процесів контролю, пов'язаних із бухгалтерським обліком, у тому числі й аудиту, знаходяться в Україні на рівні започаткування.

Саме тому актуальним залишається питання про впровадження інформаційних систем щодо практичної роботи аудиторів, функції яких можуть слугувати допоміжним фактором у проведенні перевірок.

Будь-яка діяльність (чи-то підприємницька, 


\section{ЕКОНОМІКА}

чи-то виробнича) і взагалі будь-який процес починається $з$ організації. Не є винятком і процес аудиту. «Організація аудиту, як процесу - це сукупність заходів, спрямованих на інформаційне та матеріально-технічне забезпечення процесу аудиту з метою висловлення професійної незалежної думки стосовно предмету аудиту (фінансової звітності) при дотриманні правил і принципів, встановлених законом та нормативами» [3, c. 7].

На думку О. Петрика, поняття «організація аудиту» слід визначати як систему методів, способів і засобів, норм і правил, що забезпечують ефективне здійснення аудиту та подальший його розвиток як галузі наукових знань і сфери практичної діяльності. Саме організаційними формами аудиту, на думку автора, є зовнішній та внутрішній аудит [4, с. 12].

Провівши аналіз визначень попередніх авторів, можемо сказати, що організація аудиту - це сукупність аудиторських процедур, направлених на побудову адекватної й ефективної системи бухгалтерського обліку та звітності 3 метою прийняття виважених управлінських рішень.

Для забезпечення раціональної організації аудиту необхідно розробити заходи, що передбачають зокрема такі контрольні процедури як детальний аналіз інформації та іï узагальнення; оцінка достовірності системи бухгалтерського обліку та внутрішнього контролю; вибір і застосування раціональних методів; дотримання норм i правил здійснення аудиторської вибірки й методики оцінки аудиторського ризику; підготовка та формування аудиторських висновків.

Враховуючи специфічні ознаки аудиту, його види та цілі здійснення, нами розроблена структура організації аудиторського процесу, що має такі складові:

1. Інформачійно-методична складова. Включає вивчення та оцінку діяльності господарюючого суб' єкта у рамках правового й економічного середовища. У цьому разі використовують різні джерела інформації та методи їх узагальнення для здійснення аудиторських процедур. Водночас, вагомим аспектом $є$ планування, що розпочинається 3 етапу погодження основних умов договору, а не з моменту його підписання.

2. Організаиійна складова. Включає розробку низки контрольних дій щодо забезпечення ефективної організації процесу аудиту, в т.ч. раціональної організації праці зовнішніх (незалежний аудитор) та внутрішніх (представник підприємства) аудиторів. Це дає змогу визначити мету, завдання, об'єкти та суб'єкти аудиторського процесу.
3. Процедурна складова. Включає розробку оптимального порядку проведення аудиторських процедур, які складаються 3 планування, складання програми (методики) аудиту та доведення його результатів через аудиторський висновок.

4. Прогнозно-стратегічна складова. Включає визначення та аналіз можливих ризиків у впровадженні господарської діяльності підприємства, перспектив його розвитку, а також надання рекомендацій щодо поліпшення результативності господарюючого суб'єкта та усунення виявлених недоліків. Це забезпечує здійснення оцінки прийнятих управлінських рішень і визначення майбутньої стратегії розвитку підприємства.

У ході організації аудиторського процесу слід надавати увагу якості аудиторських послуг. MCA 220 рекомендує аудиторській фірмі «....запровадити політику і процедури контролю якості, що забезпечують проведення всіх аудиторських перевірок відповідно до МСА або відповідно до національних стандартів чи навпаки» [5, с. 49]. Організаційними складовими якості аудиторських послуг визначено: політику призначення виконавців, політику прийняття на роботу, політику делегування повноважень, організацію службового зростання аудиторів, політику внутрішнього контролю якості.

Аудиторською палатою України визначено організаційно-правові основи для впровадження системи зовнішнього контролю якості аудиторських послуг. Одним із основних документів $є$ Концептуальна основа контролю аудиторської діяльності в Україні, в якій зазначено, що «характерною рисою професії незалежного аудитора є прийняття відповідальності перед громадськістю, ...що покладаються на об'єктивність i чесність аудиторів із метою підтримки впорядкованого ведення підприємницької діяльності, тощо» $[5$, с. 50$]$.

3 цього приводу О. Редько відмічає, що техніка й організація перевірок контролю якості мають бути зрозумілими, чітко викладеними й такими, що унеможливлюють суб' єктивізм і заангажованість, а результати - очікуваними. У зв'язку з цим автором запропоновано порядок зовнішньої перевірки якості аудиторських послуг, що надаються на території України приватними практикуючими та аудиторськими фірмами, занесеними до Реєстру Аудиторської палати України (АПУ) [5, с. 52].

Використання інформаційних систем і технологій не змінює методологію бухгалтерського обліку. Водночас організація і методика аудиту фінансової звітності підприємств, на яких використовуються комплексні комп'ютерні інформа- 


\section{ЕКOHOMIKA}

ційні системи підприємств (КІСП) та комп'ютерні системи бухгалтерського обліку (КСБО), зазнає вагомих й істотних змін, хоча, поза всяким сумнівом, загальна мета аудиту не змінюється. Аудитори, інформаційні системи і технології можуть використовувати та активно застосовувати як для проведення аудиту суб'єктів підприємницької діяльності, так і для автоматизації організації проведення процесу аудиту аудиторською фірмою.

Широке застосування обчислювальної техніки, управлінських інформаційних систем і систем у підприємницькій діяльності та бухгалтерському обліку поставило завдання перед аудиторами пристосовувати методики й технології проведення аудиторських робіт або вносити зміни, використовуючи спеціальні методи і комп'ютерні програми в ході проведення аудиту фінансової звітності підприємств, які використовують автоматизовані фінансово-облікові системи.

Саме тому аудит необхідно розглядати в організаційному аспекті як комп'ютерний аудит, що містить у собі використання самих комп'ютерів і сучасних інформаційних технологій, що безпосередньо й є організацією аудиторської діяльності в середовищі управлінських інформаційних систем. Такий підхід має включати в себе використання інформаційних технологій у плануванні, контролі та документуванні у ході проведення аудиторської перевірки фінансової звітності й підготовки аудиторського висновку, а також у наданні супутніх аудиту послуг.

Використання в аудиті персональних комп'ютерів дає змогу скоротити затрати часу на його проведення і в результаті створює нові можливості в організації та методиці його проведення.

Комп'ютерні системи бухгалтерського обліку дають можливість аудитору працювати в інформаційній системі клієнта, до того ж не створюючи додаткової бази даних. Відповідно, аудитор повинен мати комп'ютерні програми, що використовуються для перевірки змісту файлів клієнта, а також контрольні дані, які використовуються для комп'ютерної обробки з метою перевірки функціонування комп'ютерних програм клієнтів.

Технологія аудиту залежить як від конкретного підприємства, яке перевіряють, так і від його організаційно-правової форми господарювання, організації облікового процесу, особливостей діяльності. Крім того на технологію аудиту впливає практичний досвід і погляди самого аудитора.

Проте аудиторські програми, які використовують у перевірці, повинні відповідати певним вимогам. Кожен з існуючих програмних продуктів, представлених на вітчизняному ринку, має свої переваги й особливості, однак повністю охопити процес перевірки жоден 3 них не здатний. Тому відкритим залишається питання про розробку такого програмного забезпечення, яке б дало можливість комп'ютеризувати всі стадії власне аудиту, а також полегшити роботу в плані надання супутніх аудиту послуг.

Важливою проблемою аудиту в комп'ютерному середовищі є значна різноманітність програмного забезпечення ведення бухгалтерського обліку, що використовують підприємства різних сфер діяльності; у результаті цього аудитор не може використовувати одну й ту ж програму для різних підприємств. Зазвичай можна дані бухгалтерського обліку з використанням спеціалізованих програм або штатних засобів самої бухгалтерської програми виводити в загальнопоширені формати даних. Однак вітчизняні підприємства користуються бухгалтерськими програмами вже досить тривалий час i затрачати додаткові кошти, купуючи оновлення їх версій або спеціалізовані продукти для конвертації форматів, не всі мають змогу. Автоматизація роботи аудитора - це його інтерес, а не клієнта. Тому необхідно, щоб аудиторські програми мали властивість обробляти файли у форматах поширених в Україні, що використовуються в пакетах бухгалтерських програм.

Отже, можна зробити висновок, що використання управлінських інформаційних систем i технологій $є$ не тільки актуальним завданням i найважливішим фактором успішної роботи підприємства, а й необхідною умовою іiї виконання. Автоматизація інформаційних систем аудиту має сприяти розвитку та підвищення ефективності управління підприємством.

Організація аудиту в середовищі управлінських інформаційних систем є необхідним процесом, який підвищить якість і ефективність проведення аудиту. Для успішної реалізації даного процесу необхідно:

- мати кваліфікованих спеціалістів та комп'ютерну техніку високої продуктивності;

- розробники програмних продуктів повинні бути компетентними у сфері права, економіки та бухгалтерії, щоб створити потужні бази даних аудиторської практики;

- зорієнтувати підприємства всіх форм власності для ведення бухгалтерського обліку використовувати програмні продукти 3 комплексом напівавтоматичних алгоритмів, які б дозволяли аудитору швидко вносити й аналізувати дані 3 паперових носіїв;

- підвищити рівень комп'ютерної грамотності користувачів. 


\section{БІБЛІОГРАФІЯ}

1. Івахненков С. В. Інформаційні технології в організації бухгалтерського обліку та аудиту [Навч. посіб.] / С. В. Івахненков. - К. : ЗнанняПрес, 2003. - 349 c.

2. Івахненков С. В. Комп'ютерний аудит : контрольні методики і технології [Навч. посіб.] / С. В. Івахненков. - К. : Знання, 2005. - 286 с.

3. Сременко Д. В. Аудит агропромислових підприємств: методологія та організація: автореф. дис. ... канд. екон. наук : 08.06 .04 / Д. В. Сременко. - К., 2008. - 20 с.

4. Петрик O. А. Стан та перспективи розвитку аудиту в Україні: методологічні та організаційні аспекти: автореф. дис. ... докт. екон. наук / О. А. Петрик. - К., 2004. - С. 13-14.

5. Редько О. Ю. Якість аудиторських послуг: філософія та міфологія / О. Редько // Бухгалтерський облік і аудит. - 2009. - №1. - С. 46-54.

6. Терещенко Л. О. Комп'ютерний аудит : [Навч.-метод. посіб. для самост. вивч. дисц.] / Л. О. Терещенко, Б. В. Кудрицький. - К. : КНЕУ, 2011. $-226 \mathrm{c}$.

7. Федорова Г. В. Информационные технологии бухгалтерского учета, анализа и аудита [Учеб. пособ.] / Г. В. Федорова. - М. : Омега-Л, 2004. - $304 \mathrm{c}$. 